\title{
Are worksheets death? Words in museum education
}

\author{
Lenka Mrázová, Masaryk University, Brno
}

Delovni listi so obravnavani kot materiali, značilni za sodobne muzeje in njihovo odzivnost na izobraževalne potrebe obiskovalcev. To didaktično orodje, ki izhaja predvsem iz besedil, postopoma prehaja vširoko uporabo znotraj muzejskih služb, in kaže na njihovo odzivnost do obiskovalcev in na kompetence muzejskih delavcev, ki se ukvarjajo z njimi. Besedilo je zasnovano kot metodološki pregled osnovnih teoretičnih in predvsem praktičnih znanj s področja muzejske pedagogike, ki bi lahko pomagala pri procesu oblikovanja delovnih listov in njihovega optimalnega didaktičnega vpliva - oblike in predvsem vsebine.

Ključne besede: muzejska pedagogika, delovni listi, interpretacija dediščine muzejska publika, metodologija

Worksheets have been regarded as one of the materials which characterize modern museums and their responsiveness towards educational needs of visitors. This didactic and mainly on words based tool gradually becomes a widely used museum service, a material demonstrating both the responsiveness towards visitors, and the competence of museum workers who are engaged in working with audience. Text is intended as a methodology capturing basic theoretical and mainly practical knowledge in the field of museum education, which might help in the process of creation of worksheets and their optimal didactic impact - the form and mainly the content.

Keywords: museum education, worksheets, heritage interpretation, museum audience, methodology

W orksheets have been regarded as one of the materials which characterize modern museums and their responsiveness towards educational needs of visitors. This didactic tool gradually becomes a widely used museum service, a material demonstrating both the responsiveness towards visitors, and the competence of museum workers who are engaged in working with audience. It is not easy to elaborate educationally functional worksheets of relevant quality. Usually also another added values are expected, such as entertainment, representative character, low production and elab- oration costs for these worksheets which often must be made quickly and in provisional conditions. The material which you are holding in your hand $s^{\mathrm{T}}$ does not claim the right to represent the only possible set of approaches and topics for elaboration of worksheets. But it tries to capture basic theoretical and mainly practical knowledge in the field of museum education, which might help in the process of creation of worksheets and their optimal didactic impact - the form and mainly the content. Its aim is to give a

I This methodological material was published in Czech language (Mrázová 2012). 
helping hand to pedagogues ${ }^{2}$, lecturers and other workers in museum institutions who are engaged in the work with audience.

\section{Characteristics of museum worksheets}

It is not easy to characterise the content of the commonly used terms like worksheet, worksheets, workbook, etc. Under the term 'museum worksheets' we generally understand printed materials elaborated by museum workers, which are available to museum visitors. They are intended to complement and enliven the exhibitions and make them easier to understand.

The museum worksheets differ from the worksheets and workbooks used in schools mainly in their interconnection with a temporary or permanent exhibition, a close relationship to the exhibits and the focus laid primarily on boosting the perception and examination of these exhibits. Herewith it is a tool rather than the actual purpose of museum education.

The purpose and main function of the museum worksheets is to make the visitors observe the exhibits more thoroughly. The worksheets should show the visitors a possible way of how to regard these exhibits and offer them place for their own records, reflections and notes. To put it simply, the worksheets should help the visitors discover the collection items, so that the visitors rather keep an eye on the objects than on the worksheets. This is at the same time the most difficult aspect of the elaboration of museum worksheets. Some help can arise from appropriate impulses, instructions and tasks, which are targeted at drawing attention to the objects themselves, not only to easily available information in legends and complementary texts on the exhibition panels.

The ideal functional form of worksheets is always derived from particular permanent or temporary exhibition, pedagogical plans of individual museum pedagogues and their educational goals. Despite this, we can follow up sev-

2 For the sake of simplification, the term 'museum pedagogue' in the following text simply refers to all museum workers who are engaged in working with audience, creation of accompanying programmes and elaboration of worksheets. eral general rules which can simplify the creation process of worksheets and increase therewith the didactic effectiveness of this tool.

Worksheets can be elaborated for any types of visitors (the adults also like to test their intelligence and skills...), but the most frequent recipients of these materials remain children, mainly those in school groups. The second most appreciated category comprises the so-called family worksheets that is worksheets intended for parents with children, or grandparents with children, children accompanied by adults, etc.

\section{The role of museum worksheets}

The primary purpose of worksheets is to support the perception of exhibits by visitors. This purpose involves several functions, which the museums worksheets should fulfil to various extent. With the help of general didactics (Skalková 2007, 104-I05; similarly, e.g. Veverková 2002, I43; Průcha 1998, etc.) we can, for example, study the following functions:

- orientational and coordinative function the worksheets simplify the orientation in an exhibition and show herewith one of the possible ways of how to work with the exhibition; they should deliberately follow up the collection items exhibited and the original exhibition plan, and at the same time they should offer another new perspectives and interlinks between the information obtained;

- cognitive and systemising function - the worksheets usually contain basic knowledge, tasks and subjects linked with the topic of a temporary or permanent exhibition, their order also gives the visitors instructions, how to perceive and sort this new information;

- developmental, educational, fixative and controlling function - the worksheets with their appropriately chosen working methods in a temporary or permanent exhibition help the visitors develop their personal interest in the topic, support the education- 
al potential of museums, fixation of new knowledge, and validity check of the information acquired;

- motivational and self-educational function - the worksheets with their content and arrangement also should motivate the visitors to further interest in the topic.

In general, it can be said that worksheets give the visitors a hint how to work with an exhibition. They should contain a record and assortment of basic and most important pieces of knowledge, their fixation with the help of tasks and activities, or inspiration to individual research or working with attitudes and opinions of users.

\section{Worksheets - when yes and when no}

Museum worksheets gradually turn into a popular and widely used didactic tool, an almost common service to visitors. However, this tool and service is not always functional, beneficial to the educational process in museums. An inappropriately elaborated or used worksheet can even be counterproductive for the museum educational process. The museum pedagogy currently rather abandons the general and common use of worksheets in all temporary and permanent exhibitions and tends to their sparse but well-founded use.

Worksheets should never be purposeless, that is, they should not be elaborated only because it is expected. One of the main preconditions of well-functioning worksheets is their purposefulness with regard to the topic of a temporary or permanent exhibition, its design, character of collection items and the information communicated, as well as to the real need and space for using this material.

Worksheets in exhibitions which are, for example, rich in information are used as a logical instruction on how to understand the problem; exhibitions full of experiences and emotions, on the other hand, sometimes do not really require elaboration of accompanying didactic materials. It also depends on the conception of a museum pedagogue, how he/she intends to conceive the topic of a temporary or permanent exhibition and which method of working with these materials is supposed. The decision to create and use worksheets should always be completely within his/her authority.

The most frequent mistake is an erroneous perception of worksheets as the true essence of museum pedagogical work rather than a tool, a means of presentation of collection items and the exhibition topic to the audience.

\section{The form of worksheets}

Worksheets can be quite varied in their form, which is given by the way of their use, their extent, design and content.

In principle we can follow up two basicforms defined by the way of working with worksheets in museums (Šobáň 2007, 36-38):

- worksheets for working with a lecturer - they are used actively within accompanying museum programmes, serve as a foundation for own observations and notes, or as extension materials and a tool which, however, should not attract more attention than the programme itself and should not be dominant or disturbing with regard to the programme: "Since they take into account the commentary of a lecturer, they need not to contain formulated tasks. They are rather used for presentation of complementary photographic and information materials or offer space for written or visual artistic activities of the attendants..." (Šobáň 2007, 37);

- self-service worksheets - they place increased demands on the methodical aspect of this material, it is necessary that the tasks and activities are supplemented with instructions and additional comments, etc.: "Working with them does not require any additional explanation by the lecturer, because all the necessary information and instructions to the tasks are included in the text. This type of worksheets should of course be equipped with a key to solution of individual tasks..." (Šobáň 2007, 38). 
Another characteristic is evident from the way of use of museum worksheets (Jůva 2004, 137) - the talk is of worksheets used in following situations:

- before the museum visit - as a motivation;

- during museum activities - these worksheets are used directly in the course of a museum tour or within an activating programme which is part of a temporary or permanent exhibition;

- in work after the museum visit - as a source of information or a tool for development of further interest at home, or for subsequent work on the topic at school, or in the museum after the end of the tour or the activating programme.

The varied form of worksheets can also be defined by their extent (Jůva 2004, p. 138). You can use, for example:

- separate informative sheets - they only contain basic information on a temporary or permanent exhibition, are often designed as a typical brochure fold, which the museum visitors obtain for free when buying a ticket;

- separate worksheets - usually one page with tasks, activities and impulses to own records;

- informative booklets - text in the form of a slender brochure providing extended information on a temporary or permanent exhibition;

- workbooks - their content is similar to separate worksheets; they have the form of either a book or individual loose sheets placed in a folder;

- children catalogues;

- complete set of complementary materials.

Regarding the numerous variants of forms and the logical and thematic content of worksheets it is relatively difficult to classify these materials by their form and content. According to these criteria (Křístková, Křístek 2005, I-4) we can distinguish:

- informative worksheets - they are characterised by valuable and often very comprehensive information on the exhibition topic; their graphic design is often relatively expensive so that they have also been regarded as the representative material of educational museum activities; typologically seen, their format rather reminds of an exhibition catalogue; elaboration of this type of worksheets is connected with several risks, namely that their extent is too large and that the overall character of these materials reminds of schoolbooks;

- activating worksheets - their textual, informative and material aspects are less demanding than with the previous type of worksheets; they usually comprise simple instructions to various tasks and empty fields for own records; typologically seen, they rather remind of school workbooks; elaboration of this type of worksheets is connected with several risks, namely that they easily turn into too simple fill-in-theblanks, which mostly do not sufficiently motivate to work with the exhibition and rather lead to a fast filling in without any deeper considerations about the exhibition content;

combination of informative and activating worksheets - maybe the most widely used form in the museum practice; ideal form of these worksheets includes balanced informative and activating components, which contain both the most important professional information, and the visitors' own reflection on how they perceive the exhibition; elaboration of this type of worksheets is connected with risks of both the previous types of worksheets as well as with possible risk of shallow content but, when well-elaborated, they interconnect appropriately all the above-said advantages: they contain both the basic and most important infor- 
mation, and the impulses for an active fixation of new knowledge.

\section{Worksheets step by step}

It is not easy to create worksheets which are functional, which help the visitors to comprehend the exhibition topic and remember the most important information, which draw attention to objects and at the same time entertain the visitors. Their concrete and functional form always depends on the institution for which they are designed, on the temporary or permanent exhibition for which they are intended, on the purpose which they serve, and on the preferences and experiences of individual museum pedagogues. The elaboration of worksheets can thus only hardly be summarised in a simple general instruction, but we can generate some basic rules of creation of these materials. Respecting them will help to create worksheets which will meet the goals set out.

\section{Evaluate a temporary or permanent exhibition with regard to content and presentation.}

The first step should always be a detailed evaluation of a temporary or permanent exhibition with regard to content and presentation. Think about the topic of the temporary or permanent exbibition, about possibilities of developing this topic, about the most important exhibits, about possible points of view which are interesting or significant to visitors.

\section{Questions to contemplate}

What is the temporary/permanent exhibition about? What is the basic information on the topic? What is most important in the temporary/ permanent exhibition? What is most attractive? How does the exhibition present the topic? Which "story" it tells?

Also pay attention to space, in which the temporary or permanent exhibition is installed. The space influences both the choice of appropriate way of working with the worksheet and, to a certain extent, as well the choice of content and focus of the worksheet by the arrangement and way of installing the exhibition.

\section{Questions to contemplate}

In which space the temporary/permanent exhibition is situated? How is the temporary/permanent exhibition arranged in this space? How is the temporary/permanent exhibition installed? Which limitations or advantages for working with the worksheet result from this installation? Are there too many or rather fewer exhibits? Where are the most important exhibits? How does the ideal tour path look? Where are possible collision points for working with a group or with a large number of visitors (e.g. narrow or small spaces, poorly organised space, little space between showcases, etc.)? How to make the work here "exhibit-safe"? Where could the working with a worksheet be risky, e.g. if the visitors will want to rest or lay the worksheet somewhere? Where, on the other hand, are the conditions suitable for working with a worksheet - where the visitors can sit down, lay the sheet on a table, rest it on and fill it in comfortably?

Working with worksheets is also influenced by light conditions in a temporary or permanent exhibition. There is not always enough light for reading the information and writing it down, e.g. some installations are only illuminated by minimal light for the purpose of protection of exhibits or a dramatic accentuation of the topic or target of the exhibition; in some exhibitions the work with selected exhibits might be complicated by reflections from glass of the showcases, etc.

\section{Questions to contemplate}

How are the light conditions in a temporary or permanent exhibition? How the light changes depending on going through the exhibition? How are the light conditions in places of presumed working with a worksheet? Are the exhibits well visible (i.e. is it possible to study details, are the visitors perhaps not hindered by, for example, reflections on glass, shadow of some other exhibit, etc.)? 


\section{Think about your own pedagogical intents}

The next logical step is a consideration about own pedagogical intents concerning the given topic and space. Get clear about which part of the topic and exhibition you, as a museum pedagogue, consider important, from which perspective you want or need (e.g. due to compatibility with Framework Educational Programmes during elaboration of worksheets for schools) to present the exhibition? Temporary and permanent exhibitions usually are relatively extensive and rich in exhibits, which can be observed in various contexts and from many perspectives. Finding an optimal way of how to guide through an exhibition is crucial for creation of worksheets, otherwise it can happen that the resulting material is too extensive and exhausting. The course of your exhibition tour may or may not be compatible with the opinion of the curator who created and installed the exhibition. It is entirely legitimate to choose with the help of worksheets some other logical sequence of how to see an exhibition, another way of going it through, or, for example, only a single object to illustrate the topic, providing that the information transmitted remains professionally correct. However, you should always be well aware of the reasons for your choice, that is, why do you want and need the worksheets just in this way.

\section{Questions to contemplate}

How I intend to make the visitors familiar with the exhibition? What is to me, as a museum pedagogue, most crucial with regard to audience? What, in my opinion, should the visitors learn from the exhibition? How I want the visitors, who are working with a worksheet, go through the exhibition? Why?

\section{Choose the target group}

A very important criterion for creation of worksheets is of course represented by the exhibition visitors themselves. The choice of the target group of visitors, worksheet users, is a factor which directly determines the form of worksheets, their content, difficulty or language. To put it simply, the younger the target group for whom the worksheets are intended, the simpler the extent, graphics and content of the worksheets.

\section{Questions to contemplate}

For whom the topic of a temporary/permanent exhibition is suitable? Whom I want/need to make familiar with the exhibition topic with the help of worksheets? What are the characteristics of this visitor group? What are the risk factors, limitations, specifics of this group for the work with worksheets? How do these specifics influence the design of worksheets, their content, graphics, typology, structure of questions, tasks and information, language, etc.?

\section{Evaluate the progress of a planned educational programme}

Also important is the evaluation of the progress of a planned educational programme, which includes worksheets. It is important to realize, why do you want to include worksheets into the programme structure, where do you want include them within the programme structure, where the worksheets can help the content of the programme and how. Make sure that the worksheets and their tasks do not distract attention from the exhibition programme.

\section{Questions to contemplate}

How does the planned programme look? How is it structured? What are the main focal points? In which moments it can be supported by worksheets and in which, on the other hand, the worksheets could distract attention from the main focus of the programme? With which exhibits the programme is working? Do I want to draw attention to these main exhibits, or will I rather use worksheets to complement the information on other objects/exhibits? Is my intent to work continuously with worksheets, or will the visitors work with them only in some concrete moments of the programme?

Considerations about the previous procedural steps (evaluation of the exhibition, own 
pedagogical intents, target group of visitors, educational programme) will also verify the relevance of using worksheets to interpret the given exbibition, that is, whether or not the worksheets are suitable for this particular temporary or permanent exhibition.

\section{Choose the educational goals}

A step which is inevitable for creation of worksheets is the choice of goals of this didactic tool that is the very reason of its use. The goals form the content of worksheets and at the same time reflect their functionality. During elaboration of worksheets we are working with partial goals, that is certain knowledge and skills, to which the worksheets should lead the visitors. It is not necessary to set out too many of these goals two or three are fully sufficient, also legitimate is only a single goal. Think about what you want to teach the visitors, what you need the visitors to be aware, to know and to can. Get clear about these intended goals in the form of a binding statement, or a written statement, so that you can anytime return to their explicit formulation. For example, when you need to make sure that a question, activity, task or information in the content of worksheets is reasonable, or in retrospective evaluation of their functionality and effectiveness. Fulfilment and achievement of set out goals represent the most important evaluation factor. Formulate the worksheet goals in active declarative sentences of present tense, for example, the visitors can, know, distinguish, etc. Each of the selected activities, questions and pieces of information in worksheets should pursue and support these goals - if not, then it is unnecessary to the worksheets. The worksheet goals should always correspond to the goals and intents of both the exhibition and a possible programme, if the work with worksheets is included. The worksheets should in principle underline the exhibition topic, make it better understandable, more vivid and more profound, they should draw attention to unique details or interdisciplinary relations.

\section{Questions to contemplate}

What is the worksheet intended for? What should the worksheet support/show? What I want the visitors to learn, be aware, achieve with the help of the worksheet? Most important to me are the following pieces of knowledge, skills, feelings... Examples of formulated worksheet goals: the visitors are familiar with... can... know... will compare... will explain... will evaluate...

\section{Make a schedule}

If the worksheets are intended to be used with an exhibition, you usually have an idea of the time which you want the visitors spend filling in the worksheets. This estimated time to a certain extent influences the form, extent and contentual depth of a worksheet. In individual tasks consider the length of their solution and potential risks which might threaten or prolong their solution, and think about possible variants of how to eliminate these risks.

\section{Questions to contemplate}

How long lasts an ordinary exhibition tour? How long lasts the programme, which will include the worksheets? How much time I want the visitors spend filling in and working with the worksheets? How much time the visitors will spend reading the information or fulfilling particular tasks? Is there any risk connected with this particular task, which might prolong its fulfilment? What is it? Am I able to eliminate or minimize this risk somehow?

\section{Decide on the form of worksheets}

After having considered all the previous aspects and prior to working out the content of worksheets, it is inevitable to decide on the suitable form of worksheets. It should fully comply with conditions and responses, which you as a museum pedagogue have stipulated in considerations about the previous procedural steps. Choose the suitable form of worksheets according to particular temporary or permanent exhibition - its content and way of presentation, according to 
your own pedagogical intents, according to selected group of visitors for whom the worksheets are intended, according to the educational programme, which potentially should include the worksheets, according to particular goals which they should fulfil and time which should be spent by working with them.

\section{Questions to contemplate}

Will the worksheets be part of an accompanying programme or will they be self-service worksheets? Will I use the worksheets as a motivation for visitors before the exhibition visit, as a support during the visit, or as a review of knowledge after the end of the visit or at its end? Will the worksheets rather inform, or rather activate, or both? How will be the extent of worksheets?

\section{Choose the content and suitable exhibits}

The next step is the creation of content of the worksheets and selection of exhibits, on which the worksheets will be focused. The content will be given by pedagogical intents, with which you approach the creation of worksheets, and by the goals chosen. Afterwards it will be specified by exhibits which you will choose for the work with the worksheets. If you do not want the worksheets to be limited on only superficial information, they usually cannot work with all the objects exhibited. So, it is important to consider very thoroughly what to emphasize or, the other way round, what to omit, so that neither the worksheets nor the visitors are overloaded with information and tasks and so that it is not very time-consuming to fill the worksheets in. Selection of exhibits for the work with worksheets should be the higher, the lower the age of the target group, or the deeper you want the visitor to contemplate the exhibits or immerse emotionally in the topic. The selection should always be focused on what you intend, so that the visitors engrave on mind and put into context, which experiences they should "take home" and recall again with the filled-in worksheet, etc. It usually concerns important facts or contexts which are otherwise little known, or own experiences with the topic which represent a significant component of the educational aspect of these materials. Thorough selection of objects should thus focus on the most important, simply significant or most attractive exhibits and show their interconnection in a wider context, or, on the contrary, examine interesting details. You should always rather choose fewer exhibits and let the visitors work with them more thoroughly and more profoundly the worksheets thus can be based on only a single collection item and its more detailed presentation. Also important is to consider the distribution of selected exhibits in the exhibition premises, so that the working with worksheets is comfortable for the visitors - that is, so that the object chosen is well visible, easy to observe and examine, so that it is possible to fulfil the assigned task, or so that the working with worksheets does not interrupt the ordinary running of the exhibition and hinder the other visitors in their exhibition tour.

\section{Questions to contemplate}

Which pieces of knowledge should the visitors note down, remember, what should they become aware and explore? Which exhibits meet these criteria best? Where are these exhibits placed? Are they well visible? Can they possibly be observed by more visitors at once? Which other extending and deepening information on these exhibits I can use? Do the selected exhibits follow up each other in a logical way?

\section{Lay out the structure of worksheets}

The structure of a worksheet is one of important criteria which determine the success of a worksheet. Its logical arrangement, well-organised graphics and the choice of tasks, questions and information exert a direct influence on how the visitors will understand the topic. The structure of a worksheet can in principle follow the same methodical approach, which is usually applied during preparation and creation of the accompanying museum programmes; so it can be based on the same concepts and methods. For example, in terms of the RWCT method (Reading and 
Writing for Critical Thinking) ${ }^{3}$, the worksheets can follow up the three-stage learning cycle $\mathrm{E}$ $-\mathrm{R}-\mathrm{R}$ (evocation-realization of meaning-reflection), i.e. the initial task is making familiar with the topic, searches for previous knowledge of the topic. The following tasks and activities, just as the information recorded, already address the "core" of the problem and the last component should subsequently summarise and reflect on the problem. Following up the didactic procedures during creation of worksheets helps to keep them balanced and well-understandable. It helps to maintain the "storyline" of the worksheets in relation to selected goals and is herewith a certain guarantee of effectiveness of these materials.

\section{Questions to contemplate}

Do the tasks follow up each other in a logical way? Do they enhance the knowledge of the topic gradually? Are the worksheets well structured? Do they build on the previous knowledge of the visitors? Do the final activities reflect the most important pieces of knowledge and experiences?

\section{Change evenly and thoughtfully various types} of activities

When setting up the particular content of worksheets from various tasks, puzzles, research records, open questions etc., it is suitable to change evenly and thoughtfully various types of tasks and activities, so that the visitors employ cognitive (rational, intellectual), affective (emotional, attitudinal) as well as psychomotor (sensual, motional) skills. That is, so that the visitors explore and investigate with reason, are aware of their emotions, generate attitudes to the given topic and try out various practical skills and methods of work, production or creation, etc. Also important are research methods as the basic component of museum work. The procedures chosen

3 Reading and Writing for Critical Thinking (RWCT) is an educational method based on purposeful development of cognitive skills in learners. It proceeds from pedagogical constructivism and leads the learners to own perception of communicated information. You can see more on the website https://www.rwctic. org. should motivate the visitors to examine the objects and think about the contexts, not only to merely record the information, e.g. the requirement for a detailed description of an item will ensure its thorough examination, just as the requirement to make a drawing. Putting into context, following up the development and recording own ideas leads to a deeper consciousness of the importance of an object and to possible self-reflection or change of attitudes.

\section{Questions to contemplate}

Does each of the activities chosen support the worksheet goals? Which particular knowledge or skill will the visitors acquire? Are the tasks and activities targeted at substantial and most important knowledge and skills? Do the activities attract the attention of visitors to the exhibits and their examination? Do the activities employ various skills, are the tasks not monothematic, focused on only a single type of activity?

\section{Most frequent weaknesses}

- Textually too extensive worksheets, which remind of representative materials rather than of a functional didactic tool. Too extensive material discourages the visitors from working with worksheets.

- Overloading with script, text, pictures or information distracts attention from the temporary or permanent exhibition and the visitors lose their grip on the topic as well as on the worksheet itself. An overabundance of various markings and a too detailed division or a compact monotonous text are inappropriate in this regard.

- Distracting attention from the exhibition to worksheets and their texts. Instead of emphasizing the unique possibilities of acquiring knowledge in museums, the attention is often distracted by too many purposeless exercises.

- Useless information, incomprehensible, vaguely formulated or too extensive instructions to tasks - the worksheets often contain infor- 
mation, which from a didactic point of view is not inevitable and infests unnecessarily the space, e.g. a too long introductory narrative in worksheets intended for working with a lecturer, etc.

- Inappropriately chosen activities and tasks:

- too easy or too difficult;

- distracting too much attention from the exhibition and exhibits themselves to easily available information in accompanying materials, legends, texts etc., or the requirement for recording data which are neither relevant nor substantial (typical example is the search for date - you should always be sure that such an information is of value to the visitors, that the task is not there for itself, i.e. that it is, for example, a crucial date which the visitors should indeed know);

- distracting attention from the exhibition to worksheets, that is, tasks which do not stimulate the visitors to "raise their eyes" from the worksheets to the exhibition, e.g. crosswords, word searches, etc.; it is not necessary to give them completely up, only to place them more suitably in the structure of worksheets, e.g. to the revision and fixation part of the worksheet or among the tasks intended for individual work at home or at school; tasks without relation to objects instigate the effort to find the answers as quickly as possible, without any deeper contemplations of the content, so that a danger arises of something like a "high-speed" race among the visitors, that is filling in the worksheets and going through the exhibition as quickly as possible with lowest possible effort.

- Monothematic tasks: repeating similar questions and tasks focused always on the same type of information and knowledge, or employment of only a single skill, most frequently the verbal written language, and omitting the other skills.
- Insufficient space for the comments or observations by visitors, or a small space for the answers.

- Working with exhibits which are poorly accessible to visitors, e.g. they are placed high, are too small to be examined by more visitors at once, are situated in a narrow space where there is not enough place for everybody, etc.

- Inappropriately chosen technical parameters of worksheets can significantly reduce their functionality, whether it is a too large or too small format of the worksheets, an inappropriate choice of hardness and structure of the paper, small or poorly legible script, etc.

\section{What is important}

- Appropriate choice of objects for working with worksheets, which are significant with regard to the exhibition topic and at the same time well accessible for observation by even a large group of visitors, and their examination is not hindered by, for example, their being placed too high, or by reflections in the glass of showcases, etc.

- Worksheets should always attract attention to exhibits, support them and make them accessible.

- The amount and character of the text should correspond to primary goals and type of worksheets, the texts should be adequate to age and provide relevant information.

- Lucidity, simplicity or even austerity will surely pay off.

- Clear formulation of questions and tasks in worksheets, which should always be adequate to the target group, their age and level of knowledge.

- Questions and tasks focused on relevant and substantial information.

- Activities should rather be fewer in number, but open and motivating the visitors to reflect upon the issues, to search for relation- 
ships, to explore, and stimulating curiosity, interest and fantasy.

- It is appropriate to employ as many different skills as possible, that is not only verbal skills but, for example, drawing, mathematic or linguistic skills, and employ evenly the cognitive (rational, intellectual), affective (emotional, attitudinal) as well as psychomotor (sensual, motional) skills.

- Well-considered and balanced changing of various types of activities and skills.

- Thoroughly considered technical criteria of worksheets, that is a properly chosen format of the paper, its quality, suitable size and easily legible script, as well as well-understandable graphic design, can significantly increase the functionality and effectiveness of worksheets.

- Information on the temporary or permanent exhibition for which the worksheets are designed, and on the target group of visitors for whom they are intended. Worksheets, just as any other printed materials published by the museum, also are advertising materials, therefore they should contain the logo of the institution, name and contact, as well as the name of the author of worksheets.

- If the worksheets are intended for pupils to supplement the school teaching, they should observe the educational standards, that is currently the Framework Educational Programmes, and meet the needs of schools in relation to present-day curriculum.

\section{Evaluation of worksheets}

Worksheets should regularly be evaluated. Checking out their effectiveness is important for the museum visit itself, for a good response to the worksheets in museum visitors, and for those who create the worksheets (was I successful?, what does work?, what does not work and why?, what has to be changed? what, on the contrary, should be maintained?, what was difficult for the visitors?, what, on the contrary, was too easy?, etc.) and for the museum institution itself (what is the effect of worksheets?, does it pay off to invest time and manpower to create them?, etc.).

If you assess individual worksheets, it is necessary to focus on the pedagogical intent and goals which you wanted to achieve, and find out whether the visitors acquired the intended knowledge and information through the medium of the activities offered. Further, whether the tasks were appropriate for them and sufficiently interesting. It is also necessary to observe whether the worksheets do not attract too much attention or do not incite to fill them in without a thorough examination and working with the exhibition, or whether at all the visitors use the worksheets. Their disinterest can attest to insufficient motivation or inappropriate or incomprehensible instructions. Also to blame might be, for example, a chaotic or little attractive graphic design or an improperly chosen unsuitable format or material of the worksheets. The benchmark of success can also be the extent of filling in these materials by visitors or, for example, their verbal comments in a conversation with museum pedagogue.

A suitable tool for elimination of possible weaknesses is the pilot testing of the worksheets in practice, directly in the given temporary or permanent exhibition, on a group of visitors, for example an agreed school class, a hobby group or a group of companioned parents with children, etc. In ideal case, this pilot group is the same as the target group of visitors, both in age and assumed skills, and in number. This pilot testing provides a different view of the tasks and activities, helps to reveal weak points and make possible corrections. It also enables to verify the practical details, e.g. whether there is enough space for everybody to examine the selected objects, where are possible collision points and whether the supposed time necessary for filling in the worksheets at least roughly corresponds to real time - it usually turns out that working with worksheets goes faster in smaller groups. 


\section{Pay attention to following issues}

Did the visitors find the worksheets interesting? Do the visitors enjoy working with worksheets? Do the visitors understand the instructions to activities and tasks? Do they read the whole worksheets or do they skip some tasks/sections? Why? Where are possible problem points? Do the visitors manage to accomplish their working with worksheets in supposed time? Are there any spatial collisions during working with worksheets? Do the visitors have the skills and knowledge which should have been acquired with the help of the worksheets?

In relation to the worksheets you can, for example, consider following evaluation criteria:

Topic

Are the worksheets relevant to the exhibition? From which perspective they perceive the exhibition? If the worksheets are intended for school groups: to what extent this perspective is compatible with the Framework Educational Programmes?

\section{Space}

Are the worksheets relevant to the exhibition space? Do they follow the simple motion logic of the space (do they not lead confusedly through the exhibition space)? Is it possible to work with the exhibition worksheets comfortably (is there enough light, place to write, something to rest the worksheet against, place to make notes)? Are the worksheets safe for the collection items exhibited? Provided that a large group is working with a single type of worksheets, is there enough space for everybody to examine the exhibits?

\section{Target group of visitors}

Are the worksheets relevant to the target group? Are the tasks adequate to their age, abilities and skills? Are the instructions simple, well-understandable?

\section{Technical parameters}

Is the format of worksheets properly chosen? Is the size appropriate, are the worksheets not too large or too small? Is the type of paper suitable? Is the paper not too soft? Is it possible to write down on the paper without problems, e.g. does the script not blur? Is the font size appropriate? Are the tasks easy to read?

\section{Time}

How long does it take to tackle individual tasks? Is the supposed estimated time optimal?

\section{Structure}

○

Are the worksheets well structured? Are they not overloaded with text, information, pictures, tasks?

\section{Goals}

Has every information, instruction, task, activity its evident purpose? Do all the instructions meet and support the set out goals of worksheets?

\section{Content}

Do the tasks in worksheets work with collection items, do they draw attention to them and do they instigate more profound examination? Do the tasks stimulate thinking? Do they not require only shallow unimaginative activity? Is the information acquired important to the visitors? Do the activities change evenly? Do the worksheets not involve still the same repeating activity?

\section{The visitors' own records}

Do the worksheets offer enough space for the visitors' own activity? Is there enough space for filling in, drawing, notes?

\section{Masthead}

Do the worksheets contain the name and logo of the institution, exhibition, name of the author, validity date and the target group of visitors for which the worksheets are intended? 


\section{Conclusion}

Well-elaborated worksheets bring many advantages to the museum educational process because they facilitate the orientation of visitors in the exhibition, draw attention to significant objects and relationships, and with the help of properly chosen questions and activities they are able to captivate the visitors by the exhibition topic and events. They also offer place for taking notes of own observations and research results and generate space for expression of own attitudes and opinions on the given topic. And, last but not least, through the reflective processes they enable to fixate the acquired knowledge, experiences or skills. The worksheets, however, should always be strictly adequate to the target group of visitors, as regards the age, abilities, ways of perception and assumed previous knowledge.

Summary (methodical check list for making worksheets)

\section{What is a museum worksheet?}

- usually a printed material, which is available to visitors in order to elucidate, supplement or enliven a temporary or permanent exhibition;

- $\quad$ it is created by a museum pedagogue;

- it is intended for didactic support to the exhibition topic;

- the ideal form is always directly dependent on:

- particular temporary or permanent exhibition;

- intended way of working with this material;

- target group;

- abilities and didactic skills of a museum pedagogue.

\section{Which role the worksheets are playing in a}

\section{museum?}

- they give a hint how to work with an exhibition /orientational function/;
- they can record and sort the basic and most important knowledge/cognitive and systemizing function/;

- they fixate this knowledge with the help of tasks and activities /fixative, controlling, developmental and educational function/;

- they motivate to individual research or working with attitudes and opinions of the users /motivational, self-educational and coordinative function/.

\section{Which form the museum worksheets can have?}

With regard to the way of working with museum worksheets:

- worksheets for working with a lecturer;

- self-service worksheets (Šobáň 2007, 3638).

With regard to the way of use of worksheets we can speak of worksheets used:

- before the museum visit;

- during museum activities;

- $\quad$ in work after the museum visit (Jůva 2004, 137).

With regard to extent of worksheets we know, for example:

- separate informative sheets;

- separate worksheets;

- informative booklets;

- workbooks;

- children catalogues;

- complete set of complementary materials (Křístková, Křístek 2005, I-4).

\section{Before you begin, you should remember that:}

- worksheets are a tool, not the essence of pedagogical work in a museum;

- worksheets should never be purposeless, that is, elaborated only because it is expected, without any clear conceptual base, disregar- 
ding the focus of the exhibition or the real use of this material;

- an improperly elaborated or inappropriately used worksheet can even be counterproductive for the museum pedagogical process;

- if the worksheets are indeed supposed to be functional and purposeful, it is necessary to observe certain didactic rules and principles of the learning process, as well as further eligibility of these materials with regard to goals and topic of a temporary or permanent exhibition, or the intended way of working with the worksheets.

\section{How to proceed?}

- evaluate the temporary or permanent exhibition as regards the content and presentation /what the exhibition communicates, how, and in which space/;

- think about your own pedagogical intents concerning the given topic and space / what I want to teach, show, communicate/;

- choose the target group of visitors (worksheets should always be strictly adequate to the target group of visitors, as regards the age, abilities, ways of perception and assumed previous knowledge/;

- or, evaluate the course of the educational programme planned, if the worksheets are intended to be a part of.

! By considering these criteria you can also verify the effectiveness of using the worksheets for interpretation of the given temporary or permanent exhibition /does the worksheet to this exhibition, this topic and for this target group make sense?/.

- set out the educational goals of worksheets / particular knowledge or skill at the cognitive, affective and psychomotor level/;

- schedule the time, which the visitors should spend working with the worksheets;

- following up the educational goals, choose the suitable form/design of the worksheets; regarding the educational goals, choose the content - the worksheets should underline the topic of the exhibition, make it easier to understand, enliven and deepen, they should draw attention to unique details or interdisciplinary relations;

- an important criterion in fulfilling the content of worksheets is the selection of collection items for working with the worksheets / it is inevitable to consider thoroughly what to emphasize, what to omit, selection of objects should be distinctive and strict/;

- the structure of worksheets can in principle observe the same methodical procedure as in preparation and creation of accompanying museum programmes /e.g. in the concept of a syllabus to a lecture in the RWCT method (reading and Writing to Critical Thinking), the worksheets in a reduced form can thus follow up the three-stage learning cycle E $\mathrm{R}-\mathrm{R}$ (evocation-realization of meaningreflection), i.e. the initial task is making familiar with the topic, searches for previous knowledge of the topic; the following tasks and activities, just as the information recorded, already address the "core" of the problem and the last component should subsequently be summarising and reflective/;

- change evenly and thoughtfully various types of tasks and activities, so that the visitors employ as many different skills and working methods as possible.

The procedures chosen should motivate the visitors to examine the objects and think about the contexts, not only to merely record the information, e.g. the requirement for a detailed description of an item will ensure its thorough examination, just as the requirement to make a drawing; putting into context, following up the development and recording own ideas leads to a deeper consciousness of the importance of an object and to possible self-reflection or change of attitudes. 
Well-elaborated worksheets

- facilitate the orientation in an exhibition;

- draw attention to significant objects and relationships;

- are able to captivate the visitors by the exhibition topic and events with the help of properly chosen questions and activities;

- offer place for taking notes of own observations and research results;

- generate space for expression of own attitudes and opinions on the given topic;

- enable to fixate the acquired knowledge, experiences or skills.

\section{Povzetek}

Delovni listi so obravnavani kot materiali, ki so značilni za sodobne muzeje in njihovo odzivnost na izobraževalne potrebe obiskovalcev. To didaktično orodje postopoma prehaja vširoko uporabo znotraj muzejskih služb in je gradivo, ki kaže odzivnost do obiskovalcev in kompetence muzejskih delavcev. Ni lahko izdelati izobraževalno funkcionalnih delovnih listov ustrezne kakovosti. Običajno se pričakujejo tudi druge dodane vrednosti, kot so zabava, reprezentativni značaj, nizki stroški izdelave delovnih listov, ki jih je pogosto treba pripraviti hitro in v improviziranih pogojih. Njihov namen je pomagati pedagogom, predavateljem in drugim delavcem v muzejkkih ustanovah, ki se ukvarjajo z delom z obiskovalci.

Muzejski delovni listi se razlikujejo od šolskih delovnih listov in delovnih zvezkov, predvsem v povezavi z začasno ali stalno razstavo, tesnim odnosom do eksponatov in osredotočenostjo predvsem na spodbujanje dojemanja in pregleda teh eksponatov. Delovni listi so orodje ne pa cilj muzejskega izobraževanja. Namen in glavni namen muzejskih listov je, da obiskovalci temeljiteje opazujejo eksponate. Idealna funkcionalna oblika delovnih listov je vedno izpeljana iz posebnih stalnih ali začasnih razstav, pedagoških načrtov posameznih muzejkkih pedagogov in njihovih vzgojnih ciljev.

Dobro izdelani delovni listi prinašajo številne prednosti muzejskemu vzgojnemu procesu, saj olajšajo orientacijo obiskovalcev na razstavi, opozarjajo na pomembne predmete in odnose ter $s$ pomočjo pravilno izbranih vprašanj in aktivnosti pritegnejo obiskovalce. Ponujajo tudi prostor za zapisovanje lastnih opazovanj in rezultatov raziskav ter ustvarjajo prostor za izražanje lastnih stališč in mnenj o dani temi. In nenazadnje, s pomočjo refleksivnih procesov omogočajo fiksiranje pridobljenega znanja, izkušenj ali spretnosti. Delovni listi pa morajo biti vedno strogo prilagojeni ciljni skupini obiskovalcev, glede na starost, sposobnosti, načine zaznavanja in predznanje.

\section{Summary}

Worksheets have been regarded as one of the materials which characterize modern museums and their responsiveness towards educational needs of visitors. This didactic tool gradually becomes a widely used museum service, a material demonstrating both the responsiveness towards visitors, and the competence of museum workers who are engaged in working with audience. It is not easy to elaborate educationally functional worksheets of relevant quality. Usually also another added values are expected, such as entertainment, representative character, low production and elaboration costs for these worksheets which often must be made quickly and in provisional conditions. Its aim is to give a helping hand to pedagogues, lecturers and other workers in museum institutions who are engaged in the work with audience.

The museum worksheets differ from the worksheets and workbooks used in schools mainly in their interconnection with a temporary or permanent exhibition, a close relationship to the exhibits and the focus laid primarily on boosting the perception and examination of these exhibits. Herewith it is a tool rather than the actual purpose of museum education. The purpose and main function of the museum worksheets is to make the visitors observe the exhibits more thoroughly. The ideal functional form of worksheets is always derived from particular permanent or temporary exhibition, pedagogical plans of individual museum pedagogues and their educational goals.

Well-elaborated worksheets bring many advantages to the museum educational process because they facilitate the orientation of visitors in the exhibition, draw attention to significant objects and relationships, and with the help of properly chosen questions and activities they are able to captivate the visitors by the exhibition topic 
and events. They also offer place for taking notes of own observations and research results and generate space for expression of own attitudes and opinions on the given topic. And, last but not least, through the reflective processes they enable to fixate the acquired knowledge, experiences or skills. The worksheets, however, should always be strictly adequate to the target group of visitors, as regards the age, abilities, ways of perception and assumed previous knowledge.

\section{Sources}

Jůva, V. 2004. Détské muzeum: edukační fenomén pro 2I. století. Brno: Paido.

Křístková, M. and N. Kř́stek. 2006. "Pracovní listy." In Projekt Škola a muzeum pod jednou strechou: 2004-2006 [CD-ROM]. Praha: Národní galerie v Praze.

Mrázová, L. 2012. Tvorba pracovních listů. Metodický materiál. Brno: Metodické centrum muzejní pedagogiky, Moravské zemské muzeum.

"Reading and Writing for Critical Thinking." https://www.rwctic.org

Průcha, J. 1998. Učebnice: teorie a analýzy edukačního média Př́ručka pro studenty, učitele, autory a výzkumné pracovníky. Brno: Paido.

Skalková, J. 2007. Obecná didaktika. 2nd ed. Praha: Grada Publishing.

Šobáň, M. 2007. Škola muzejni pedagogiky 6: Stručná teorie a praxe muzejni pedagogiky. Olomouc: Univerzita Palackého v Olomouci.

Veverková, H. 2002. “Učivo.” In Zdeněk Kalhous and Otto Obst, Školni didaktika, I2I-I 48. Praha: Portál. 